$$
\begin{aligned}
& \text { SB } 273 \\
& .955
\end{aligned}
$$





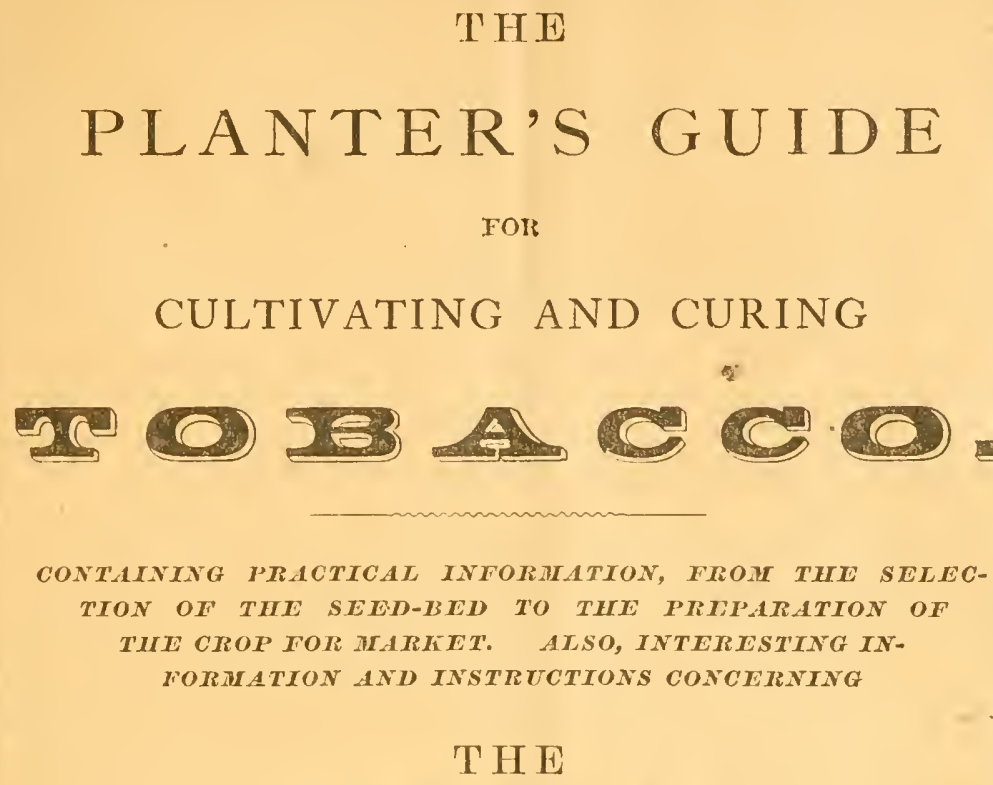

CONTAINING PRACTICAL INFORMATION, FROM THE SELECTION OF THE SEED-BED TO THE PRTIARATION OF TIIE CROP FOR MARKET. ALSO, INTERESTING INFORMATION AND INSTRUCTIONS CONCERNING

THE

\section{THE SHELTON TOBACCO CURING COMPANY,}

OF ASHEVILLE, NORTH CAROLINA.

E. J. ASTON, Secretary.

V. K. SPEAR, President. 



\section{INTRODUCTION.}

In publishing and cirenlating this Pamphlet, our object is to call the attention of 'l'obaceo Growers to the Shelton 'Tobaceo Hanger; but, at the same time, it has been our ain in preparing it, to collect the best practical and most reliable information possible; and, in fact, to make it what its title claims, "'lue Planter"s Guide."

'To accomplish this, we have consulted some of the most successful Tobacco Planter's; the result of which is, instead of one man's ideas on this subject, we present you with the combined experience of many. We have also consulted the following excellent publications on the Cultivation and Curing of Tobacco, and acknowledge our indebtedness to their Authors and Publishers: "Reports of the Department of Agrieulture," published at the Government Printing Oflice, Washington, D.C.; " 'Tobaceo Culture," published by Orange Judd \& Co., New York; "How 'Tobaceo is laised and Prepared for Market," published by the southern Fertilizing Company, Richmond, Va., and "Shelton"s Prize Essay on the Culture and Management of 'Tobacco."

Our Patent Ifanger is the invention of Mr. Samuel C. Shelton, who is well known as the first successful tobacco grower in Western North Carolina. This invention is destined to supply a long-felt want which none were better aware of or better prepared to meet than the Inventor; he having had twentyfive year's' experience in cultisating, euring and manufacturing tobacco. For exhibiting the best Leaf 'Cobacco he has received the following awards :-

$\begin{array}{ccccc}\text { First Preminm at Rateigh, North Carotina, } & 1871 . \\ \text {. } & \text { " } & \text { " Richmond, Virginia, } & 1872 . \\ \text { " } & \text { ". } & \text {. } & \text { Vienna Exposition, } & 1873 .\end{array}$

For information concerning the advantages of the Hanger we refer you to page 13; for instructions in making and using, to the pages following, inclucling articles on "Preparations for Curing and Stringing," "Gathering the Crop," and "Stringing the Leaves." 'The results of " Experinents in Weight," "Testimonials," and other information of interest, may be found on the closing parges of this l'amphlet.

All of which is respectfully submittel by the

SIIELTON TOBACCO CURING COMPANY.

15opies of this Pumphlet sent free on application to the Company. 



\section{PLANTER'S GUIDE}

\section{FOl: \\ Cultivating and Curing Tobacco.}

\section{('ULTIVATION OF TOBACCO.}

'The enltivation of tohaceo in the United States has become so extensive as to embrace at least forty-two States and Territories, which produce an anmual crop of about three hundred million pounds, with a value to the producers of at least forty million dollars.

Therefore it is a matter of great importance to the planter, how to enltivate and prepare it for market in the best manner, and at the least possible expense.

After making eareful observations, we believe that tobaceo, with skilful eulture and management, is the most remunerative of any erop grown, and a poor business if grown and handled without the ipplication of those prineiples and appliances which extensive experience has proved to be the best adapted to the end desired.

\section{VARIEIIES OF TOBACCO.}

Loudion enumerates fourteen different speeies of tobacco, of which only one, the Nicotiana Tabaceum, is generally eultivated. Of this species there are many rarieties, each possessing qualities supposed to be deriverl from elimate, soil, and modes of enltivation.

Few, if any, plants are so much affected by the peculiarities of the soil on which it is grown, by cireumstances of fertilization and mode of curing, as tobacco. For example, the Broad Leaf Orinoco, when enltivated on the rich and highly manured lands of Kentueky, produees the dark, strong-flavored "shipping tobaceo;" and when grown on the light gray soil of Virginia or North Carolina, with but little or no manure, and eured in a close barn with artificial heat, will produce the bright "wrappers" for which these States are so famous. 
The variety known as Connecticut Seer Leaf is grown principally in Massachusetts, Connecticut, New York, Pennsylvania and Ohio, and is used in the manufacture of eigars, both for fillers and wrappers. Florida, portions of Ohio, Pennsylviuia and other States, produce the Cuba, which is also used in the manufacture of cigars. Maryland, Virginia, North Carolina, Kentucky, Tennessee, Missouri and other States, cultivate many varieties, prominent among which are the Big and Little Orinoco (or Broad and Narrow Leaf Orinoco), Big and Little Frederick, Bhe and Yellow Pryor, Big Stem, White Stem, Gooch, and numerous other kinds that bear different names in different localities; and though mostly hybrids, they each possess some good qualities which recommend them to the growers.

SEED.

Whatever the variety cultivated, it is very important that you have good seed for sowing. In order to secure this hereafter, a fer of the earliest and most promising plants should be selected from the seedbed, transplanted in some favorable spot, and carefully attended thronghont the season. In time these should be pruned of all except the large leaves, and only the two topmost branches left to bloom. These plants should be carefully suckered, and about the first of October, every pod not thoroughly ripe, plucked off and thrown away, and the others gathered and put in a dry place to cure. When dry, the seed should be rubbed out, sifted, and placed in a dry ressel, and kept where no dampness can reach them. Seed preserved in this manner will keep for years. By giving a little extra attention to your seedplants, you can increase the yield and improve the quality of your tobaceo.

\section{SELEC'TION AND PREPARATION OF PLAN'T-BEDS.}

In selecting a place for plant-berls, remember that you wish to obtain early and vigorous plants ; therefore, take a rich, warm hillside, protected by timber or otherwise. Red lands are usually unsuited for this purpose. Never use wet or cold land. After finding a suitable place, select a dry time during the month of December or January, - the sooner the better, - rake off the leares, lay down skids (about three inches in diameter), three feet apart, across which lay a bed of wood five or six feet wide, and high enough to burn for about an hour and a lialf and yet leave a sufficient quantity to remove and kindle in another place. 
After the fire has burned the length of time specified, move it the width of the first layer, then throw on brush, a good bed of wood, and continuc as before. Every furmer ought to provide himself with iron hooks for pulling plant-bed fires. If it is possible to injure land by hard burning, we have never experienced it ; and think that where one berl is injured by burning, ten are injured for the want of it. For every ten thousand plants required, there onght to be at least ten yards square of plant-berl. A bed of this size will supply more than the number mentioned, but it is much better to have some for your neighlor than to be under the necessity of begging plants.

After burning, the land should remain untouched a few weeks, that the rains and frosts may assist in pulverizing the soil; then with a mattock, dig up the bed withont turning it over, and pulverize thoronghly with a loe and rake. Remove all the roots, spread a light coating of stable manme, chop it in, rake again, and the bed is ready for sowing. A large tablespoonful of seed to the ten yards square is enough to sow. This should be carefully mixed with sifted ashes, abont hulf of it sown one way, and the other half by walking across the first sowing. By this the seed will be more regularly distributed. After seeding, the land should be rolled or trodden until it is smootl. Now is the time to manure. We consider horse manure collected under corer (and free from litter or grass seed) to be the best for this purpose. Chop it fine, and spread a coating (say half an inch or more) evenly over the bed. This should be the last manuring mless the spring is very diry, when a light top-dressing oceasionally will be beneficial.

As to the use of guano on plant-beds, we are not prepared to recommend it as highly as stable manure. We will add, that in the absence of this manure, a light dressing of plaster will be of service; but if you have good stable manure, "let well enough alone;" for if these directions as to land and management are followed, there is abont as much chance to fail in plants as to fatil of going to sleep at night after a lard day's work burning lanr.

About three weeks after sowing, the bed should again be rolled or trodien, and covered with fine brush twigs to prevent its drying up, and protect it from the frost. The brush should not be remored until the plants are large enongh to nearly corer the gromul.

There are few circumstances under which a plant-bed in the right locality, well burnt and maumed, shonk be watered. We are disposed to think that watering is nseless mnless the spring is very dry. 


\section{PREPARATION OF NEW LAND.}

First take up every growth not too large to grub, and throw them into heaps. 'Then cut the small trees, the brush of which throw on the grub heaps; then eut and remove the larger timber. After the ground has been cleaned off it should be conltered at least three times; then harrow and rake it to pulverize the soil and remove the roots. It should now be laid off at a distance of three feet each way and hillerl. The hilling is very important, as a plow in new land will not prepare it right, and "whaterer is worth doing is worth doing well." The manuring of new land, though tronblesome, pays well.

We would recommend it to be applied in the hill if the land is rough, as broadcast will waste much of it the first year. Thin ridge land will produce a beautiful crop with a tablespoonful of guano to the hill. The second year it may be manured as other land; for if the first year's work is well done, it will be prepared to receive manure broadeast. New land should be hilled at least three weeks before transplanting, and while the land is moist, so that the soil will become compact enough to retain moisture, that the plant may thrive without rain after being set out.

\section{PREPARATION OF OI.D I,AND.}

A gray, gravelly soil, with manure, will make a fine article of tobacco if the manure is properly applied.

On common corn land the application of two hundred pounds of Peruvian guano per acre (or other equally good fertilizer) applied broadeast, will insure a fine crop; but if the present crop is the object, it may be made with one half this quantity applied in the hill.

We have succeeded well by the application of guano in drills. After the land has been thoronghly plowed, lay it off in rows three feet apart, and in these strew the fertilizer. Plow on each side of the rows (turning the furrows in) to cover the manure and form continnous beds, which should afterwards be nicely hilled. We think all upland should be hilled. About one lumdred and twenty pounds of guano is enough per acre when drilled. Land for raising shipping tobaceo slonld be more heavily manured; say for an acre, sis or eight cords of manure spread broadcast and plowed under; and in addition from two to four hundred pounds of some good fertilizer applied in drills. Ashes is a superior fertilizer for tobaceo of any kind, on any soil. In the Northern and Middle States, where lands are high and the seasons short, the growers of tobaceo resort to a system of high 
manuring, for the purpose of forcing the plants to mature and increasing their production. With them it is quite common to apply ten or twelve cords of stable manure, and in addition to this, from two to five hundred pounds of guano per aere.

\section{'TRANSPLAN'TING.}

When the plants are four or five inches high in the beds they are ready to set out in the hills. As a rule we prefer a medium-sized plant, because the larger the plant the more moisture and sustenance it requires, and the small plant is safer, but not so far advanced as the suedium or larger one.

After giving that part of the bed from which you wish to remove plants a thorough soaking with water, for the purpose of softening the soil to prevent the breaking off of the finer roots, remore the plants carefully and wash or shake off all the plant-bed soil in order to give them a fresh free start in the new soil. Take great care of them, and do not place so many together that they will be crushed or bruised, nor keep them out of the ground until the tencler roots dry up, but take them at once to the field and drop one on each hill, to be followed immediately by the planter, who should take hold of it near the roots with the thumb and forefinger of the left hand and with the right hand smooth down, or in other words, straighten out, the roots. Then, with a peg about six inches long, make a hole in the eentre of the hill large enongh to admit the roots without their touching on the sides; also make it deep enough to take in the longest roots without bending them.

Put in the plant carefully as deep as the bud; then, with the peg and thumb of the left land, press the soil firmly to the roots, and draw the earth around the plant so as to fill the entire hole. The best time to transfer the plants from the bed to the hills is when the soil is moist, but not so wet as to cause it to bake around the roots and liil them, or prevent their getting an early start. If the season is very (iry, before setting out, take the dry earth from the tops of the hills, set the plants late in the day, giving them the benefit of the night dew, and before the dew has dried off in the morning, cover them with straw, brush, leares, or anything suitable.

'This covering should remain until rain falls or until the plants get a good start. 'This re consider the best plan that ean be adopted under these circumstances. We do not approve of watering, because it has a tendency to make the soil bake, as mentioned above; but when it becomes necessary, from a continued drought, after watering 
the hill, corer the spot with dry earth, and it will tend to prevent baking.

\section{REPLANTING.}

This should be attended to as soon as you are satisfied the plant is weak or has failed, because you should have as little difference in the growth of your plants as possible. By excreising proper care in the first planting you will have but little replanting to do. We believe that cramped and crooked roots, air admitted to the roots by careless plauting, and the bruising and crushing of plants by rough handling, are nearly, if not quite, all the eauses of a poor "stand," providing the land has been properly prepared and is in good condition at the time of planting.

\section{CU'T-WORMS.}

Soon after setting out the plants, look sharp for long black or brown worms, which burrow in the hills and destroy the plants. Unearth and kill them every morning as long as they can be found. They seldom trouble new lind to any great extent. The best time and method we know of for destroying them is to plow up the land during the winter and freeze them.

\section{CULTIVATION OF NEIV IAAND.}

The main secret is to keep it elean and well stirred. In new land this may be done by two good workings in the proper time, though a third working will often be very beneficial. If the land is freshly hilled, about two weeks after planting, the hills should be scraped down, and a little fiesh earth drawn around each plant. Abont three weeks after this it should be hilled up, and in ordinary cases this will be sufficient, except to keep down the sprouts that may put up. Tobacco ought not to be worked after topping; as it will bruise and break the leares. Plowing smooth new land once (at the last working) is of service; but if it is rough and stumpy, keep a plow out of it altogether.

\section{CULTIVATION OF OLD LAND.}

Old land requires more work than new. As soon as the plants get sufficient hold, narrow up your enltivator, so as not to disturb the roots, and go through it once for the first hocing. Then cut up the remaining grass and weeds with a hoe, and lerel the soil around the plants, stirring it slightly. In ten clays or a fortnight, go orer it again with a plow or cultivator, twice in a row, using a short single- 
tree to aroid injuring the plants. This time you can stir the ground more freely around the plants, and should hill them slightly in hoeing, being careful not to cover any of the leaves. After this it is better to perform all the work with hand labor, in order to save the plants from injury. Stir the gromnd with a hoe as often as necessary to keep down the weeds.

\section{IVOPMING.}

If the worms are numerous, the plants should be thoroughly examined at least twice a week. Destroy not only the worms, but all the eggs that can be found; or, what is still better, seck ont and destroy the flies which deposit these eggs. 'These flies are gray in color, with yellow spots on each side of the body, and may be found about sunset flitting about the weeds and flowers, extracting their juices by means of their peculiar tongue, which is four or five inches in length. The Jamestown weed, or "Jimson" weed, as it is commonly called, which bears a white, bell-shaped blossom, is rery attractive to these flies. Miny of them may be destroyed by dropping a little of the following mixture into these blossons: One ounce of cobalt, dissolved in one pint of water and sweetened with some kind of syrup. But this is equally as fattal to the blossoms as to the flies; therefore we give you the following instructions for making an artificial substitute, which will prove to be more durable than the natural flower, and quite als effective. The ladies ean hest perform this work, as they happily possess more taste and skill in such matters.

Procure for their use a quire of white paper and a bottle of mucilagre. Then make a small block of suital)le size and shape, on which to form the cone, and furnish them with a natural flower to imitate. If you have no blossom of the Jamestown weed, let them try theil powers of imitation in making a "morning-glory." After forming the cone, elip it around the rim and enrl slightly, to make it look as much like a flower as possible. Attach them to branches or bushes, and place them in your thickest growth of tobacco. They should be supplied with a few drops of the poison every evening, and it may be necessary to replace the flowers after a heary rain. By following the above instructions you will save much trouble in worming. A flock of turkeys will also be found very useful in catching and destroying worms, and can only be equalled by childlen to whom premiums have been offereci. 
TOPPING.

This operation consists in taking off the top of the plant, and must be done for the purpose of concentrating the strength of the land in such number of leares as will best mature.

It should be performed as soon as the seed-buds show themselves.

No rule can be given which will apply to all cases, as mucl depends on the variety grown, the condition of the soil, and whether your crop is well alvanced or otherwise. With an early crop on rich soil, do not take off more than one or two of the top leaves, if any at all ; while on the contrary, if your soil is poor and crop late, top down to that number of leaves which, according to your judgment, will fully ripen. The number of leaves to be left on the plant varies, in different sections and under clifferent circumstances, from eight to twenty.

\section{PRIMING.}

This consists in removing the lower leaves of the plant to the height of five or six inches from the ground ; these are removed for two reasons. First, if allowed to remain, they will be made worthless by coming in contact with the soil. Second, to improve the quality of the remaining leaves, - as in topping. Do not commence priming until the principal part of your topping is done ; then continue it regularly, and save every leaf with as much care as if it were gold. Thongh light in weight, you will get some as fine tobacco from these primings as any in your crop, and it is simply folly to throw them away.

\section{SUCKERING.}

The suckers are small leaves that start from the base of the larger ones after the plant has been topped. They make their appearance at the top first, and should be continually nipped off as fast as they become Iarge enough to get hold of; otherwise they will retard the growth and prevent the early maturing of the plant.

\section{REMIARKS.}

We have described the operations of worming, topping, priming and suckering, separately and in the regular order which they first appear; but they cannot be wholly performed and finally disposed of in the same manner.

Soon after you commence worming, the buds make their appearance and claim their share of your attention : then follows the priming and 
suckering. The first suckers will appear in about a week after topping, and will afterwards require plucking two or three times in the same number of' weeks.

The worming must still be attended to. Thus it will be seen that two or more of these are continued operations and can be performed in connection with each other. To the experienced Tobacco Grower, much that we have written in the way of explanation may seem altogether needless; but our intention is to embody, in this pamphlet, all the practical information needed by new beginners, together with valuable lints to all Tobacco Growers.

\section{CONSTRUCTING BARNS.}

\section{SIZE OF BARNS.}

For Coal or Flue curing, we believe in small barus, as the heat can be more evenly distributed in them. The old barns (16x16 inside) used in the old process will answer the purpose; though if the barn is to be built, we recommend it to be not more than four tiers high, placing the lower ticr-poles eight feet from the ground, and the height between the tiers, about the average length of the leaves you grow. Small farmers might build even smaller ones, say of that size which the force they work can fill in one or two days, calculating the hangers five inches apart, and a "hand" to fill one lundred hangers per day.

\section{MA'IERIALS.}

Logs, well "chinked" and "daubed" with clay, inside and out, are probably the best materials for walls; but in localities where they cannot be readily procured, any construction which can be made to hold the heat will answer. "Adobe," or bricks clried in the sun (made of clay and a small quantity of straw mixed to prevent them from cracking), will make a good wall. For tier-poles, use either straight poles or sawed lumber $2 \times 4$; arrange them to extend from back to front, and do this while building the walls, if made of logs or adobe. The roof can be made of any material which will retain the heat. 'The doorway should be in the middle of the wall (six feet high and four feet wide), and to extend to the ground or floor ; furnish it with a good close shutter or door. 


\section{FLUES.}

In the construction of flues, stone of any lind that will not burst or crumble when exposel to the heat, brick or sheet-iron corered with mortar, cement or clay, to receive and deliver a steady heat, are the principal materials used.

As applied to a tobacco barn, they usually consist of two furnaces built inside (near the right and left front corners as you enter), with the ends projecting throngh the walls far enough to allow the feeddoors to open from the ontside. Connected with these, on the inside, are fumnels or passages, sixteen or eighteen inches in cliameter, which extend around three sides of the barn (ahont two feet fiom the walls), and serve to distribute the heat erenly, and conrey the smoke to the chimney or outlet. 'Tlis chimney, or' stem, as commonly arranged, is sitnated at the centre of the rear wall where the pipes or flues meet and join it.

Extend the ehimney through the wall, and far enough beyond to prevent all danger from sparks. In order to insure a good draught, the chimmey shonkl be about fonr inches higher than the month of the furnace. 'There are patent flues in use which have given very good satisfaction, and we advise those who intend curing with flues to examine them before building the common flue.

\section{HOUSES FOR AIR-CURING.}

The drying house should be so constructed as to allow the free circulation of air among the leares, and protect them, when necessary, from the direct action of the sun, wind and rain. Any building will answer the purpose which has a good roof, and windows and air-holes enough to regulate the circulation.

In erecting a building especially for this purpose, place a ventilator on the roof, and board the sides of the honse perpendicularly, hanging every other board on hinges.

The inside should be divided by poles or timbers, into "rooms," to accommodate the length of your sticks, and also into tiers, one above the other, about two feet apart, more or less, according to the length of the leares gromn.

Before proceeding to the gathering and curing of the crop, we call your attention to omr 


\title{
TOBACCO HANGER,
}

Patented April 6, 1Sr5,

\author{
BY SAMUELC. SHELTON.
}

This derice is especially adapted to curing the leaves, by gathering from the stalk, when fully ripe, and stringing them on the wire attachment; thereby aroiding the splitting, cutting, transporting and curing of the stalk.

Erery experienced Tobacco Grower realizes more fully each year that he is lrandling at heary expense, and material injury to the leaf, a stalk entirely worthless as a commodity; and while readily admitting the fact, he has still continned to follow the old and universal plan of curing, for want of something better.

We now present a device by which he can cure the grathered leares alone, and let the stalk remain in the field to enrich the land.

We will enumerate some of the advantages gained by its use:

First. - Economy of room. By putting a larger quantity on a hanger and an increased number of hangers in a barn, you are enablerl to cure at least four times the usual quantity in the same barn.

Second. - It takes less time and less heat to cure this four times as much, than one house full by the old process.

Third. - It takes less time to gather and prepare it for market.

Fourth. - In curing, it sares at least three fourths of the coal or fuel, and as much in time.

Fifth. - It saves all the trouble of stripping after it is cured, and one half the trouble in assorting.

Sixth. - It enables you to employ cheap lathor in gathering, thereby saving nearly one half the usual expense.

Serenth. - It sares the tearing and bruising of the leares, and useless weight consequent upon the presence of the stalk.

Eighth. - It allows you to save the leaves as they ripen, and let the green ones remain to mature.

Ninth. - It saves every leaf in the crop, and leares no waste or rubbish. 
Tenth. - There is much less danger of injury from "running," on account of the absence of the stalk.

Eleventh. - It improves the quility and increases the weight, by preventing the sap from forcing the oil, gum, or other valnable properties of the leaf, back in to the stall.

Twelfth. - It enables the planter to cure his tobacco thoroughly, and greatly improves the color and texture.

By the use of this hanger in air-curing, all of these adrantages are gained, except the saving of fuel; and for this claim we substitute one of rast importance to all who cure their tobacco in this manner, which is, the avoidance of "pole-sweat," or rotting of the stem and leaf while curing.

\section{PREPARATIONS FOR CURING ON TIIE SHELTON IIANGER.}

This device is made either by attaching wire to the sticks now in use, or to others made for the purpose.

Cut the wire the length of the stick, and attach it at the centre, either by giving it one tmin around the stick, or passing it through a hole made with a brad-awl, and giving it two or three twists, leaving the wire parallel with the stick, with the ends in opposite directions. The wire may be attached to any part of the stick, thongh we recommend attaching it at the centre.

\section{SCAFFOLD.}

When ready to commence "priming" or gathering your crop, erect a seaffold near the barn, on which to hang the tobacco after it is strung. 'This may be constructed of poles, scantling or other material, and supported by forked sticks or horses. These poles should be the same distance apart as those in the barn. A barn 16x16, with four "rooms," six full tiers and a roof tier, will contain one thousand hangers filled with tobacco. A scaffold may be built to hold this number or less, as the tobaceo can be removed to the barn whenever the seaffold is full.

\section{PREPARATIONS FOR STRINGING.}

Support the hangers on two upright posts or sticks, having notehes in the ends to keep the hangers in position. Place two hangers parallel with each other, and two feet apart; then construct a table or 
bench, about four feet in length and two in width, near each end of the hangers. The following diagram illustrates the scaffold, hangers, tables and position of operators :-
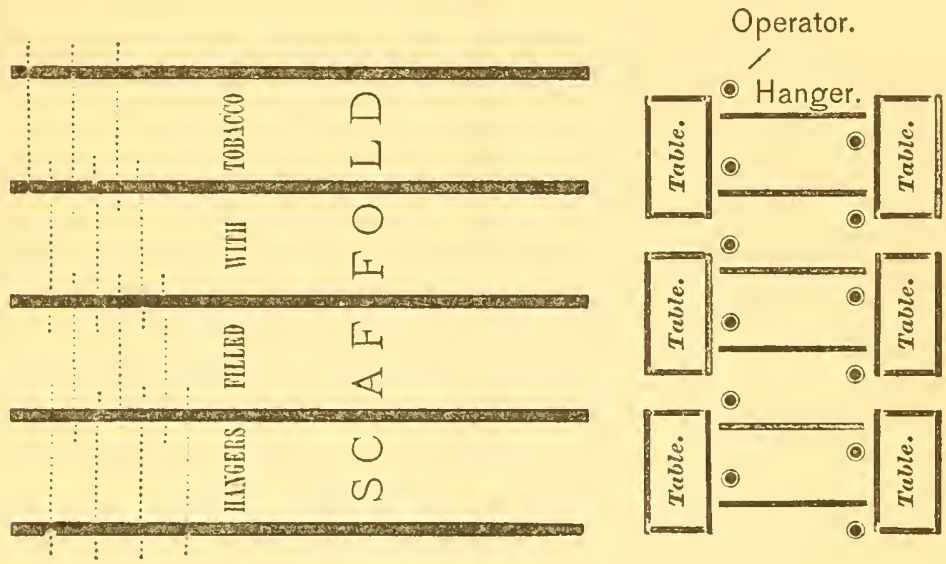

GA'THERING THE CROP.

If the plant is fully ripe, remove all the leaves at once, keeping the stems together, and transport them to the scaffold with a sled, wagon, barrow, basket, or in any way most convenient.

When a plant is only partially ripe, if you desire to make a fine, uniform crop, remove only the ripe leaves, leaving the others to mature.

When the leaves are about ripe, they present a spotted appearance and become brittle. By bending them short, they will break before doubling.

\section{STRINGING TUE IEAVES.}

As the leares are brought from the field, place them on the tables with the stems, or butts, toward the operators; string them by passing the end of the wire through the stems; let the first leaf liang on one side of the stick, the second on the opposite side, and the third on the same side as the first.

Continue in this mamer until the stick is full, allowing sufficient space at the ends to rest on the tier-poles.

We have strung and cured from one hundred and twenty to one 
hundred and thirty leaves on a single hanger; but would not recommend stringing more than one humdred arerage leaves on a four-feet hanger, as they will cure in less time and with less heat than a larger number.

Two persons can string on one hanger at the same time. As soon as a hanger is filled, place it on the scafiold and proceed with another in the same manner. An ordinary "hand" will string one hundred hangers per day, while a more active person, with little experience, will string one hundred and twenty-five or upward.

\section{CURING "GOLD LEAF."}

The bright, lemon-colore 1 tobacco, used for fancy nrappers, shonld be cured with charcoal or flues. The finest quality of this is raised in Virginia, North Carolina, and portions of Kentucky, Tennessee and Missonri, and is cured in the following manner :-

Fill the barn (placing the hangers about five inches apart) and hang your thermometer on one of the lower tiers, near the centre. Start your fires so as to produce an uniform heat of about ninety degrees, Fahrenheit, and continue this temperature until the tobacco becomes sufliciently yellow.

No exact time can be given for yellowing, as tobacco which contains a superabundance of sap, or is very large, requires more time than that which is smaller or has less sap.

An ordinary crop will require from twenty-four to thirty-six hours. Do not allow it to become real bright yellow before raising the heat, as it continues to yellow for several hour's after.

Now raise the lieat three degrees per foour nutil you arrive at a temperature of one lundred and ten degrees, and remain at this point until the ends of the leaves curl slightly; after which, continne to advance at the sume rate as before (three degrees per hour) until you arrive at one hundred and twenty. To prevent "sweating" during this time, the safest plan that can be adopted is, to keep the door open. It is not necessary to keep widle open, though there is no objection to its remaining so, except that it regnires more fuel to secure the heat desired. At the begiming of the season, in curing the first tobacco in each barn, or in curing heavy or green tobacco, this plan should invariably be adopted, otherwise the dimpness will endanger its injury from sweating.

Having arrived at one lmudred and twenty, the door shonld now be closed; and moder farorable circumstances may be closed at the 
start, but must be opened often while advaneing from ninety-five to one hundred and ten degrees.

If sweating commences (which may be known by the leaves becoming damp and pliable), raise the heat and open the door, for the purpose of creating a current of hot air, which will soon eause it to disappear.

The leaf should now be cured before arriving at a temperature of one humdred and thirty ; therefore advance only at the rate of two degrees per hour for the next five hours. Then, in curing the stem, raise the heat five degrees per hour until you arrive at a temperature of from one hundred and sixty-five to one hundred and seventy-five degrees. By this time the stems should be thoroughly cured; but if not, go no higher, but continue the heat, at the highest point reached, until they are.

We condense the instructions for regulating the heat, in the form of a table for reference :

Remain at $90^{\circ}$ until suffieiently yellow.

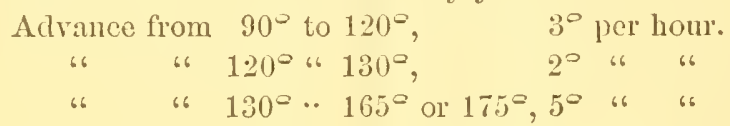

Usually the leares begin to curl at the ends by the time one hundred and ten is reached, which makes it umecessary to stop at this point.

This table is simple, and as reliable as any that can be given. There are cases when crops are not in ordinary condition; then no table can be followed successfully. If you see the face side of the leaves tuming a reddish-brown color, the heat must be increased a little; while, on the other liand, if they begin to show reddish spots near the edges and on both sides, you have too much heat. While advancing from one hundred and twenty to one humdred and thirty (in curing the leaf), care must he taken that you do not lower the temperature below the highest point reached. Never go above one hmuled and eighty degrees, unless you desire to scorch your tobaceo; which, some claim, improves the flavor, though it injures the color. In curing with tharcoal, a barn $16 \times 16$ will require nine fires; one $18 \times 18$, twelve fires, and one 20x20, sixteen fires, so arranged as to distribute the heat evenly. If the wind should blow heavily against one side of the barn, raise the fires on that side a little above the others, and thus partially counteract its effect.

After curing, close the barn tightly in order to keep the tobacco dry. 


\section{CURING SHIPPING TOBACCO.}

Let it remain in the barn or on the scaffold for three or four days. or until it begins to yellow; then make slow fires of logs, so arranged as to blaze but little. Care should be taken that the tobaceo does not sweat from too much heat ; but if it should, proceed as with bright wrappers.

"Houseburn" is rot, caused by heating the tobacco by overcrowding.

If it should heat before firing, start the fires at once. After the leares are well dried, increase the heat until the stems are cured; providing you do not go above a temperature of one hundrer and seventy-five degrees in so doing. The dark, heary shipping tobaceo is cured by firing immediately after it is loused.

\section{SUN-CIRING.}

This requires an abundance of scafolds, and well-rentilated honses. The latter can be made of any desired length, but only as wide as will give free ventilation. The scaftold should be on the side giving most shelter from the winds, while it seenres the full heat of the sun; and near the honse, that the tobaceo may be readily transferred from one to the other. The best results are obtained when the temperature is from sixty-five to seventy-five degrees, with a certian degree of moisture in the atmosphere. When the tobaceo is on the seaffolds, protect it from the winds. If you have a rery hot, dry day, which will eure it too rapidly to produce the resired color, close up the hangers on the scaflold, and it will have a tendeney to "slow" the process. Four or five days is enongh on the scaffold ; then put it into a well-lighted and well-rentilated honse, where it should be kept and thoroughly cured by opening the doors and windows whenever the weather is favorable. After it is cured, close $и$ p the house and let the tobacco remain until you are ready to assort it.

\section{AIR-CURING.}

In air-curing, house your tobacco immediately after gathering; and during favorable weather, open your doors and ventilators that the air may circulate freely. It is necessary to exclnde the rain and dampness, which materially damage the tobacco and injure its color. After it is nearly cured, do not give it full ventilation during the prevalence of high winds; a stove is very useful in preventing too much dampness, in case of continned wet weather. 


\section{SIIEA'TIYG OR FERMENTING.}

Cigar tobacco is subjected to a process of fermentation, called "sweating," which should be carefully conducted, for on this depends the color, and, in a large degree, the flaror of the tobacco. Place it in heaps about six feet in cliameter, and cover them with blankets or anything that will press lightly and exclude the air. In about twenty-four hours it will commence to ferment: and when it becomes so hot inside that the hand camnot well bear it, break up the heaps and repack. placing the heated tobaceo on the outside, and again cover with cloths. Repeat until all the heat is gone, which generally takes fiom tive to six weels.

\section{ASSOR'TING.}

The rariety of tobaceo grown, and the market for which it is intemied, must largely govern the planter during this operation. It shonk be performed when the leares are moist enough to handle without being injured. The usual custom is to make but three grades, which are distinguished by diflerent names, such as first, second and thirel qualities, mannfacturing, slipping and lugs, or bright. medium and inll.

These grarles or qualities are principally composed of ripe, overripe and umripe leares at the time of gathering.

If you tie it in bundles or "hands" (which we belicre to he work thrown away, besiles injuring one of the best leaves in each bundle), form them with from six to ten leaves each, of uniform length and (.olor.

\section{BLLKINT.}

If your nonse has a ground-floor, cither lay down boarts or build raised platforms three or fonr feet in width, and construct perpendicular encls or bulkhearls, to keep the tobacco in position. Commence at one end. and after straightening out the tobacen, lay a row on one sicle the full lengtly of the platform, with the stems ont and evenly arranged. Then lay a row on the opposite side, allowing the ends of the leares to lap over those of the first row abont five inches, and so continue to pack closely. Place hoards and weights on top of the bulk, leaving the sides open. This will keep the leaves moist, and, at the same time, allow the stems to hecome dry enough for packing. While in bulk examine it occasionally, and if it shonld heat. or not dry sufficiently, orerhaul and repack it loosely withont reighting the top. 


\section{PACKING.}

When the large or heavy portiou of the stem becomes dry enongh to break easily (with the leaf yet soft and pliable), the tobacco is in proper condition for packing. If any portion of it is too soft or has an ill smell, it should be made sweet and dry by a few hours' sum.

If it has to be shipped a great distance, we would recommend packing in hogsheads, placing each layer across the one below it. Tobacco of fine quality sliould not be pressed too hard, as it will surely be injured thereby.

\section{COMPARATIVE STATEMENTS.}

In order to show more clearly the advantages gained by using the Patent Hanger, we make the following comparative statements of the two methods of gathering and curing; and though they only apply to one section of the country, as far as prices of labor and coal are concerned, yet the percentage saved will be nearly the same in all cases; consequently the comount saved will be greater in sections where labor and fuel are more expensive. A barn $16 \times 16$ will contain two thousand pounds of tobacco on the Sheiton IIangers, and can be cured with one hundred bushels of coal in two days or less; while to cure the same quantity on the stalk requires fon barus, or four cmings in one barn of three days each, which will consume at least one hundred bushels of coal at each curing, or four humdred bushels in all, and require the attention of a man for twelve days and nights.

\section{COST OF GATIERING AND CURING ON SIELTON HANGER.}

To gather and cure one barn containing two thousand pounds after curing requires, -

\section{Gathering.}

3 men one day $@ 75$ cents . . . . . . . $\$ 225$

17 women and children (a) 40 cents . . . . . 680

\section{CORING.}

1 man two days and nights $\propto 7$ to cents each . . 300 100 bushels coal $a$ j) cents . . . . . . . 500 


\section{CURING ON THE STALK.}

To cure two thousand pounds by the old process will require four barns, and the cost will be as follows:-

\section{Gatilering.}

24 men one day@75 cents (to fill four barns) . . . $\$ 1800$

\section{Cuning.}

4 men three days and nights@75 cents each . . . 1800 400 bushels coal (100 at each barn) @ j cents . . . 2000

'Total, $\$ 5600$

Cost of curing on Patent Hanger _ . . . . . 1705

Difference in cost of curing 2000 pounds . . . . \$3895

By using the Patent Hanger you can save from sixty-five to seventy per cent of the usual cost of gathering and curing your crop, besides increasing its value from eight to ten per cent, by producing a more uniform color, improring the texture and increasing the weight. There are other adrautages to be deriver from its use, all of which will hecome apparent to those who try it. For instance, the cost of hanling the green stalks from the field to the barn is wholly avoided. This is no small item, and liar it heen included in the cost of gathering by the old process, would have made a still greater difference in faror of the Hanger. However, we do not elaim to save all the expense of gathering and curing a crop.

\section{COAL AND AIR CURING.}

Growers of tobacco in nearly all parts of the country (except New England) who have formerly practised air-enring, are gradually adopting the quicker and more profitable method of curing in two or three days by artificial heat. By the latter mode of curing, tobaceo is much improved in body, texture and color. Eren in the New England States, we find that air-curing does not fully answer their requirements. At a recent meeting of the Commecticut Valley Agricultural Institute, Professor Stockbridge, of Amherst College, in speaking of air-curing, said, " The curing process is defective; by the slow, gradual process much of the essential narcotic oil is lost." He also referred to " a new system of curing, largely adopted in other States," and said, "This artificial curing retains all the virtue of the tobaceo, in fact increases its esseutial oils." 


\section{EXPEPINEN'T IN WEIGIJT.}

We now give you the actual result of an experiment made during the past seasou, for the express purpose of decicling this question: Does tobacco cured off the stalk lose or gain in weight? Some contencled that it would lose, others that it would gain; while a majority of those who expressed their opinion on the subject thought it would make no difference in the weight, whether cured on of off the stalk. Although convinced by the laws of nature that it must necessarily gain, we only claimed, previous to making this experiment, that it lost nothing. It is evident that each leaf, either in dying or drying, feels back a large portion of its substance throngh the same channels that supplier it. 'The most casual observer of nature cannot have failed to notice this fact. The grass, the weeds, the corn, and every tree, shrub or plant, asserts it in the most nnmistakable manner. Tobacco cannot be exempt from this law of nature.

The finc or thin portions of the leaf are the first to cure; next the small and large fibres, and lastly the stem.

When curer on the stalk, the stalk is the last to cure, and much of that which is necessary to give the leaf "body" is forced back into the stalk, causing it to weigh more, and the leaf less.

Again, in curing by artificial heat, the longer time tobaceo is "fired" or subjected to heat after the leaf" is cured, the less it will weigh; therefore, in firing, the extra time required to cure the stalk, you are lessening the weight of the leaves. In making this test, two hundred average-size plants were selected, divided into two lots of one hundred each, and weighed. Lot No. 1 weighed 231 lbs. 3 oz. ; No. 2, 222 lbs. $13 \mathrm{oz}$. The leares were stripped from Lot No. 1, and cured on the Shelton Hangers, and the stalks were enred separately. Lot No. 2 was cured on the stalks, with the following results : -

\section{CURED ON SHEITON HANGERS.}

Weight of 100 plants before curing

" leares and stalks after curing

Shrinkage in curing Weight of stalks after curing .
231 lbs. 3 oz. 38 lbs. 13 oz. 192 los. $6 \mathrm{oz}$. 13 lbs. 6 oz. 25 lbs. $7 \mathrm{oz}$. 
CURED ON STALKS.

Weight of 100 plants before curing _ • • . $222 \mathrm{lbs} .13 \mathrm{oz}$.

"6 leaves and stalks after curing . . 37 lbs. $10 \mathrm{oz}$.

Slirinkage in curing . . . . . . $185 \mathrm{lbs} .3 \mathrm{oz}$.

Weight of stalks after curing . . . . . $15 \mathrm{lbs} .5 \mathrm{oz}$.

66 leaves 6 . . . . . 22 lbs. 5 oz.

Thus you will notice a difference of 3 pounds 2 ounces in favor of Lot No. 1, cured on our Patent Hangers. In reply, you will naturally say that this lot weighed 8 pounds 6 ounces more than No. 2 before curing, which is very true; but we find, by dividing the weight of the green plants ( 231 pounds 3 ounces) by the number of pounds of cured leaves ( 25 pounds 7 ounces), that it required 9 pounds $1_{2}^{1}$ ounces of green plants to produce one pound of cured leaves; and shows that the difference in the two lots of green tobacco ( 8 pounds 6 ounces) was not sufficient to produce a pound of cured leaves; though, allowing it had been, there is yet a difference of 2 pounds 2 onnces in our faror, or a gain of more than eight per cent in weight over the old method of curing.

Any farmer can easily make a similar test and satisfy himself as to the truth of this statement. In making an experiment of this kind, if you cure by artificial heat, and both lots in one barn at the same time, do not forget to remove that on the Hangers after it is cured, instead of allowing it to remain while the stalks of the other lot are curing. 


\title{
TESTIMONIALS FROM PROMINENT TOBACCO GROIVERS.
}

\author{
Marsirall, Madison Co., N.C., \\ November 6, 1875 .
}

E. J. Aston, Esq.,

Secretary Shelton Tobacco Curing Co., sheville, N.C.

Dear Sir, - In reply to your request for the result of my experience with "The Shelton Tobacco Hanger," I have to say that I have given it a fair trial on three barns of tobacco, and take pleasure in prononneing it a perfect victory over the old method of curing, for the following reasons:-

I can put a crop into the barns in less time, in better order, and at much less expense, than in the old way. I can cure at least twice as much in a barn with much less time, labor and fuel. When cured, the stripping is done, and much less time and labor is required to sort it. There is also less danger of its "punning." In curing with the Hangers the labor is so light that women and children can perform it.

Tobaceo cured on the Hangers is funer in quality and more uniform in color than that cured on the stalk. Not a leaf is lost by your process; but one leaf dropped from the Hanger in ny three barus while curing; and the absence of stalks and litter around the barns and fields makes as marked a difference to the eye as that of tidy and slovenly housekeeping.

I may also ackl, that it wonld have been impossible for me to have saved my erop this season with my present supply of barns, without the use of the "Shelton Hangers."

Yours truly,

T. J. ROLLINS.

Danville, VA., November 2, 1875.

E. J. Aston,

Secretary Shelton Tobaceo Curing Co.

Dear Sir, - In reply to your inquiries in regard to the "Slielton Tobacco Hanger," I will say, that I luve tried it practically, and am entirely satisfied that it is a useful invention. I intend to nse it more exteusively in future.

Very respectfully,

IV. T. SUTHERLIN. 
Houstonville, Iredell Co., N.C.,

Norember 27, 1875.

Mr. E. J. Aston, Asheville N.C.

Dear Sir, - Youl letter is at hand. In answer, I will say, I did not succeed in getting my wire in time to give the "Ianger" as fair a trial as I wisherl. I tried one barn only, but am satisfied it is a great improvement on the old way of curing tobacco, the time being so much shorter in curing the leaf alone.

The economy in conl is also an item to the tobacco growers. From my experience this year, I shall follow it up. My neighbor's are pleased with what has been tried.

Yours respectfully,

JOHN H. DALTON.

[From one who contended that tobacco would lose in weight when cured off the stalk.]

Pea Ridge, Tennessee,

November 29, 1875.

Mr. E. J. Aston.

Dear Sir, - I tried the Hanger on a small scale, and only with a view of testing the weight. I took 172 pounds of green tobacco, of uniform quality, cut in the usual way, and weighed off 86 pounds, and stripped of the leaves and put up in your way. The other half I hmy np in the old way. Alter stripping the cured tobacco I weighed each separately, and cannot perceive the least difference in weight. I am therefore prepared to say that there is no loss by reason of the leares being stripped off while green.

$$
\text { Yours, \&c., }
$$

M. E. WILCOX.

\section{Riverside, Buncume Co., N.C., \\ November 23,1875 .}

E. J. $\Lambda$ ston, Esq.

Ser. S. T. C.Cu.

I take pleasure in complying with your request for a detailed statement of my experience with the "Shelton 'Tobacco Hangers." I curer the whole crop of about forty-four acres on the Hangers with a force of fonr men and eleven women and chiltren, who put it on the 
Hangers and cured it in sixteen working days. It cost for labol $\$ 153.47$. I nsed in curing about one third of the charcoal that would have been required the old way.

I eured 1150 Hlanger's in one 16 -font barn (six tiers in the body), the tobacco on each Hanger weighing two and one half pounds, making 2875 ponnds of net tobaceo, which was cured in three rlays with 150 bushels of coal.

The tobacco is cured bright and of splendid body. In fact the (arop is the finest I ever made. After a day's experience a brisk hand can string one hundred sticks, which will make two hundred and fifty pounds net cured tobacco. There is no doubt in my mind of the absolute success of this invention, as it adds to the weight, eures the tobacco neater and brighter, and at half the expense.

V'ery respectfully,

C. H. SORRELS.

Salisburit Fair, October $24,1875$.

'This is to rertify that I have used the "Shelton Tobacco Hanger" with perfect snceess. I fully endorse it for all the inventor elaims.

PHILLIP SOMERS.

Berea, Granyithe Co., N.C., Dec, 4. 1875.

Mr. S. C. Shelton,

L1sherille, A.C.

Dear Sir, - I used your Patent Tobacco IIanger in enring one barn of primings, and succeeded far beyond my expectations. I think it is a very good invention for curing tobaceo uniformly bright. . . . . I realized $\$ 10.00$ per cwt. for primings, which, had they been cured in the usual way, would not have brought more than $\$ 2.50$ or $\$ 3.00$ per erit.

Very respectfully,

WESLEY S. LYON.

Onr Hanger received a diploma at the Agricultural Fair lately held in Salisbury, N.C. At the Virginia State Fair, held at Richmond, our application was received too late to allow of its being regularly entered, but the Committee kindly gave us permission and space to exhibit it, and from the Examining Committee we received honorable 
mention of its merits; which was all that eonld be given under the circumstances.

\section{FAFII RIGHTS.}

Farm rights, authorizing the holder to use one thonsand Hangers (or less), for a single year, $\$ 5.00$, and $\$ 2.50$ for each additional thousand. These rights or licenses can be obtained from any of our allthorized agents, or on application, by mail or otherwise, to the Secretary of the Company. Remit money by draft, money order or registered letter. No license genume unless signed by the President and Secretary of the Company, and comntersigned by the agent who issues it.

\section{IVIRE.}

We recommend the use of No. 17 galvanized wire in making the Hangers, as this size seems most suitable, and the galvanizing prerents it from rusting. The cost of this will be about $\$ 5.00$ per thousand sticks. If the wire should vary one or two sizes from that recommended, it will make no material difference. In procuring your license, either from the Company or any of its agents, you will receive information of the nearest or most convenient point for purchasing wire.

\section{AGENTA.}

Responsible agents are wanted in each county to introduce our Patent Ilanger, with whom liberal arrangements will be male.

For particulars, address

SHELTON TOBACCO ('LRING CO., Asheville, N.C. 


